\title{
ANALYSIS OF THE CLONAL RELATIONSHIP AMONG CLINICAL ISOLATES OF Salmonella enterica SEROVAR INFANTIS BY DIFFERENT TYPING METHODS
}

\author{
Luis A. MERINO(1), María C. RONCONI(1), Margarita M. NAVIA(2), Joaquim RUIZ(2), Josep M. SIERRA(2), Norma B. CECH(3), \\ Norma S. LODEIRO(3) \& Jordi VILA(2)
}

\begin{abstract}
SUMMARY
Salmonella Infantis has been the second most common serovar in Argentina in the last two years, being isolated mostly from paediatric hospitalised patients. In order to determine the clonal relationship among Salmonella Infantis strains, we examined 15 isolates from paediatric patient faeces in Argentina (12 geographically related and 3 geographically non-related) by using antimicrobial susceptibility, plasmid profiling, repetitive extragenic palindromic (REP) PCR, enterobacterial repetitive intergenic consensus (ERIC) PCR, and low-frequency restriction analysis of chromosomal DNA by pulsed field gel electrophoresis (PFGE). Four Spanish strains were included as controls of clonal diversity in molecular techniques. Antibiotype and plasmid profile was not useful as epidemiological tools. PFGE and REP-PCR were able to discriminate between Argentinean and Spanish isolates of Salmonella Infantis allowing to detect genetically related strains in three different cities. This finding indicates that a possible spread of a clone of this serovar in the North-eastern Region of Argentina has taken place in 1998.
\end{abstract}

KEYWORDS: Salmonella Infantis; Typing; Pulse Field Gel Electrophoresis, Polymerase Chain Reaction; Argentina.

\section{INTRODUCTION}

Infections caused by Salmonella strains can produce symptoms ranging in severity from intestinal disturbances to death, especially in neonates and immunocompromised patients ${ }^{15}$. Salmonella Infantis has been the second most common serovar in Argentina in the last two years, being isolated mostly from paediatric hospitalised patients ${ }^{25}$. In order to have an effective surveillance and to develop rational control strategies for this important human disease, the availability of detailed and accurate data related to the epidemiology of Salmonella is crucial.

Various typing techniques have been used in epidemiological studies to differentiate isolates of Salmonella serovars, but only a few of them have been used to discriminate Salmonella Infantis strains, since this serovar is infrequently encountered causing human disease in developed countries $^{8,17,23}$. The applied epidemiological tools include biotyping, phage typing, colicine typing, antimicrobial susceptibility testing, plasmid profiling, restriction endonuclease analysis of whole chromosomal DNA by pulsed field gel electrophoresis (PFGE), repetitive extragenic palindromic (REP) sequences analysis by $\mathrm{PCR}$, enterobacterial repetitive intergenic consensus (ERIC) analysis by PCR, restriction fragment length polymorphism (RFLP) of 16S rRNA and insertion sequence IS200 $23,14,22$.

In the present study, we examined strains of Salmonella Infantis isolated in the Northeast of Argentina from paediatric patients by several typing methods and evidence for the clonal spread of genetically related strains is presented.

Table 1

Dates and cities of isolation of Salmonella Infantis strains

\begin{tabular}{llc}
\hline Strain & City of origin of isolates & Date of isolation $(\mathrm{mm} / \mathrm{dd} / \mathrm{yy})$ \\
\hline SP30 & Pcia. R. Sáenz Peña & $02 / 04 / 98$ \\
SP31 & Pcia. R. Sáenz Peña & $02 / 11 / 98$ \\
SP32 & Pcia. R. Sáenz Peña & $02 / 17 / 98$ \\
SP33 & Pcia. R. Sáenz Peña & $02 / 19 / 98$ \\
SP34 & Pcia. R. Sáenz Peña & $02 / 23 / 98$ \\
SP94 & Pcia. R. Sáenz Peña & $08 / 10 / 98$ \\
SP97 & Pcia. R. Sáenz Peña & $08 / 26 / 98$ \\
SP98 & Pcia. R. Sáenz Peña & $08 / 30 / 98$ \\
SP99 & Pcia. R. Sáenz Peña & $09 / 01 / 98$ \\
SP100 & Pcia. R. Sáenz Peña & $09 / 03 / 98$ \\
SP102 & Pcia. R. Sáenz Peña & $09 / 04 / 98$ \\
SP103 & Pcia. R. Sáenz Peña & $09 / 04 / 98$ \\
HV141 & Corrientes & $03 / 08 / 98$ \\
HV2 & Corrientes & $02 / 17 / 98$ \\
HG1 & Juan José Castelli & $12 / 15 / 97$ \\
\hline
\end{tabular}




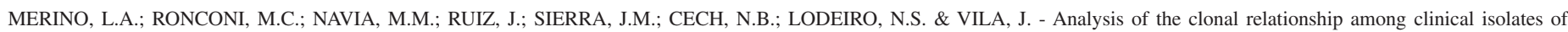
Salmonella enterica serovar Infantis by different typing methods. Rev. Inst. Med. trop. S. Paulo, 45(3):119-123, 2003.

\section{MATERIALS AND METHODS}

Bacterial strains: Among 29 isolates of Salmonella Infantis obtained from paediatric patients faeces during 1998 in the Northeast of Argentina, 15 strains were examined in this study. Twelve strains (SP30 to SP103) were isolated in Presidencia Roque Sáenz Peña, Province of Chaco. Three epidemiologically unrelated strains were included in this study for comparison: one strain (HG1) was isolated in Juan José Castelli, Province of Chaco, and two strains (HV2 and HV141) were collected in Corrientes, Province of Corrientes. Additionally, four Spanish clinical strains provided by the Spanish Collection of Type Cultures (University of Valencia, Spain) were included as controls of clonal diversity. Bacteria were identified to specie level by conventional methods ${ }^{2}$. The Argentinean strains were serotyped in the Service of Enterobacterias of National Reference Laboratory in Buenos Aires (Argentina).

Patients: All patients from which the isolates were obtained were hospitalised and their ages ranged from 0 to 2.25 years (Average: 8.2 months). Only four of them had potable water provision in their houses.

Antimicrobial susceptibility tests: were performed by an agar diffusion disk method according to the standards outlined by the National Committee for Clinical Laboratory Standards ${ }^{20}$. The commercial disks (Britania Laboratories, Buenos Aires, Argentina) used were: ampicillin $10 \mu \mathrm{g}$ (AMP), cephalothin $30 \mu \mathrm{g}$ (CEP), cefotaxime $30 \mu \mathrm{g}$ (CTX), neomycine $30 \mu \mathrm{g}$ (NEO), gentamicin $10 \mu \mathrm{g}$ (GEN), tetracycline $30 \mu \mathrm{g}$ (TET), furazolidone $300 \mu \mathrm{g}$ (FUR), chloramphenicol $30 \mu \mathrm{g}$ (CMP), trimethoprim/sulfamethoxazole 1.25/23.75 $\mu$ g (TMS), nalidixic acid 30 $\mu \mathrm{g}$ (NAL), ciprofloxacin $5 \mu \mathrm{g}$ (CIP), colistin $10 \mu \mathrm{g}$ (COL), and fosfomycin $50 \mu \mathrm{g}$ (FOS). Escherichia coli 25922, Staphylococcus aureus ATCC 25923, Pseudomonas aeruginosa ATCC 27853 and Enterococcus faecalis ATCC 29212 were tested as quality control organisms.

DNA extraction: Plasmids were extracted by the alkaline lysis described previously by KADO \& $\mathrm{LIU}^{7}$ and modified by NAKAMURA et al. ${ }^{19}$. For each PCR-based technique, $25 \mu \mathrm{l}$ of boiled bacterial suspension were used according to GALLARDO et al. ${ }^{4}$. The DNA for low-frequency restriction analysis by pulsed field gel electrophoresis was prepared as described previously by MATUSHEK et al. ${ }^{12}$.

Plasmid profiling: Extracted plasmid DNA was electrophoresed on $0.7 \%$ horizontal agarose gels (BioRad) in Tris-Acetate-EDTA buffer (Sigma) for $16 \mathrm{~h}$ to $20 \mathrm{~V}$, and stained with ethidium bromide solution $(0.5 \mu \mathrm{g} / \mathrm{ml})$. The molecular sizes of the plasmids were assessed by comparison with plasmids from Escherichia coli V517.

Repetitive extragenic palindromic (REP) PCR: REP-PCR fingerprinting was carried out following the method previously described by GALLARDO et $a l .{ }^{4}$ using the primer 5'-GCG CCG ICA TGC GGC ATT-3' (MWG-Biotech). Samples of each PCR end-product were analysed on agarose $1.5 \%$ gels containing ethidium bromide $0.5 \mu \mathrm{g} / \mathrm{ml}$. Four Spanish strains were included for comparison.

Enterobacterial repetitive intergenic consensus (ERIC) PCR: ERIC-PCR was carried out by the method described by BEYER et al..$^{\text {: }}$ : 1 initial cycle at $94{ }^{\circ} \mathrm{C}$ for $1 \mathrm{~min}, 30$ cycles of denaturalization at $95{ }^{\circ} \mathrm{C}$ for $1 \mathrm{~min}$, annealing at $52^{\circ} \mathrm{C}$ for $1 \mathrm{~min}$, and extension at $65^{\circ} \mathrm{C}$ for $8 \mathrm{~min}$, with a single final extension step at $65{ }^{\circ} \mathrm{C}$ for $16 \mathrm{~min}$. We used the following primers (MWG-Biotech): ERIC1 (5'-ATG TAA GCT CCT GGG GAT TCA C-3') and ERIC2 (5'-AAG TAA GTG ACT GGG GTG AGC G-3'). Samples of each PCR end-product were analysed on agarose $1.5 \%$ gels containing ethidium bromide $0.5 \mu \mathrm{g} / \mathrm{ml}$. Two Spanish strains were also included for comparison.

Low-frequency restriction analysis of chromosomal DNA by pulsed field gel electrophoresis (PFGE): Total genomic DNA was digested with $\mathrm{XbaI}$ (Promega) and separated in 1\% agarose gels with a contour-clamped homogeneous-field apparatus (CHEF-DRIII, Bio-Rad). It was run under $200 \mathrm{~V}$, with the pulse time increasing from 5 to 8 for 20 $\mathrm{h}$. This study was repeated using XhoI (Pharmacia Biotech) as restriction enzyme, under the conditions described above. Two strains of Spanish Salmonella Infantis were included for comparison.

Fingerprints interpretation: Analysis of the patterns was performed by visual inspection. Two isolates were said to have the same electrophoretic profile when their band patterns were identical. Minor differences in band intensity were not considered. PFGE patterns were interpreted according to the criteria suggested by TENOVER et al. ${ }^{27}$. Isolates were considered genetically indistinguishable if they possessed PFGE patterns with the same number and same size of bands. Closely related strains differed by changes consistent with a single event ( 2 or 3 bands differences) or two independent events (4 to 6 band differences), respectively. Unrelated strains differed by three or more independent genetic events ( $\geq 7$ band differences).

\section{RESULTS}

Resistance to more than one of the antimicrobial agents tested was detected in all of the isolates studied. All strains were resistant to AMP and CEP and were susceptible to NAL, CIP, TET, CMP, NEO, FOS and COL. Since the isolates presented variable susceptibilities to CTX, GEN, and FUR, these drugs were used for comparison between strains.

Three different plasmid profiles, each including one or two plasmids with approximate molecular sizes ranging from 54 to $130 \mathrm{~Kb}$ were found in the 15 strains analysed. $130 \mathrm{~Kb}$ plasmid was the more frequent. The relationship between plasmid profiles and antimicrobial resistance patterns to selected drugs is shown in Table 2.

Fingerprinting with REP1 primer generated identical patterns between Argentinean strains but different to those of Spanish isolates (Fig. 1).

Patterns obtained with ERIC-PCR methods showed few clearly visible bands and other faint bands among both Argentinean and Spanish strains, which are not enough to differentiate them (Fig. 2).

Fingerprinting with $\mathrm{XbaI}$ digestion produced 14 fragments (Fig. 3) and with $X h o I$ digestion produced 15 fragments, all of them clearly distinguishable. The patterns generated by PFGE XbaI digestion were identical for all the Argentinean strains despite their geographical origin or date of isolation. However, the Spanish controls did produce two different patterns (Results not shown). Similar results were obtained after XhoI digestion. The patterns obtained with $X b a \mathrm{I}$ and $\mathrm{XhoI}$ were stable and reproducible when repeated analysis of these strains was performed under identically conditions of digestion and electrophoresis. 
Table 2

Relationship between antibiotypes and plasmid profiles of Salmonella Infantis strains

\begin{tabular}{lcl}
\hline Antibiotypes & $\begin{array}{c}\text { Approx. plasmid } \\
\text { sizes (Kb) }\end{array}$ & Strains \\
\hline CTX $^{\mathrm{R}}$ GEN $^{\mathrm{R}}$ FUR $\left.^{\mathrm{R}}\right)$ & 130 & SP30, SP31, SP32, \\
& 130,70 & SP33, HV2, SP102 \\
& 130 & $\mathrm{SP} 97, \mathrm{SP} 98, \mathrm{SP} 100$ \\
$\left(\mathrm{CTX}^{\mathrm{S}} \mathrm{GEN}^{\mathrm{S}} \mathrm{FUR}^{\mathrm{S}}\right)$ & 130,70 & $\mathrm{SP} 141$ \\
$\left(\mathrm{CTX}^{\mathrm{S}} \mathrm{GEN}^{\mathrm{R}} \mathrm{FUR}^{\mathrm{S}}\right)$ & 130,70 & $\mathrm{HG} 1$ \\
$\left(\mathrm{CTX}^{\mathrm{S}} \mathrm{GEN}^{\mathrm{R}}\right.$ FUR $\left.^{\mathrm{R}}\right)$ & 54 & $\mathrm{SP} 34, \mathrm{SP} 94, \mathrm{SP} 103$ \\
\hline
\end{tabular}

CTX: cefotaxime, GEN: gentamicin, FUR: furazolidone, S: susceptible, R: resistant.

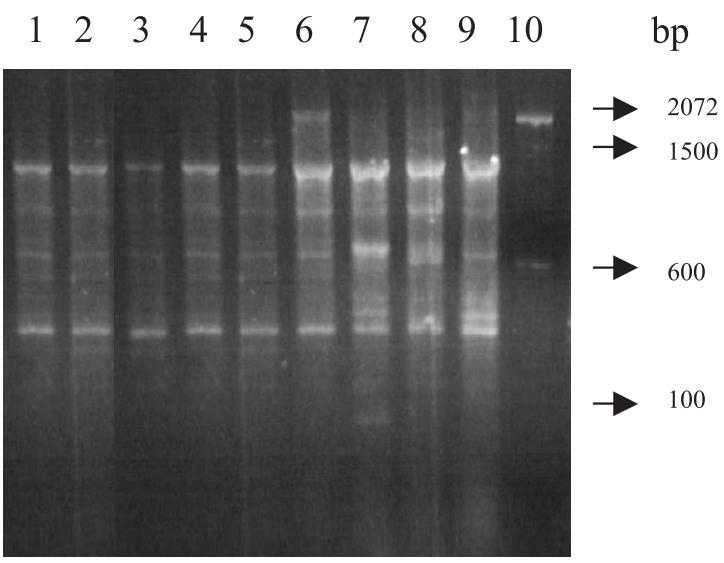

Fig. 1 - REP PCR-based molecular typing. Lanes 1-5: Selected Argentinean strains; lanes 47: Spanish strains; lane 8: 100 bp DNA Ladder

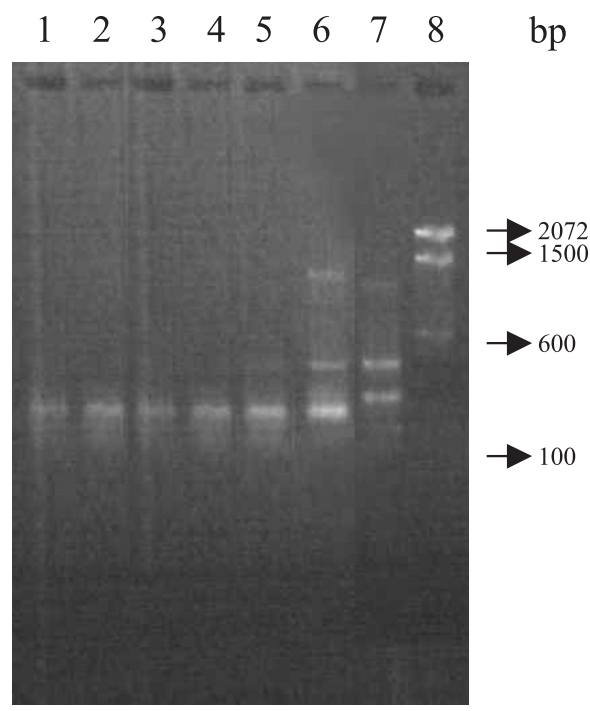

Fig. 2 - ERIC PCR-based molecular typing. Lanes 1-5: Argentinean strains; lanes 6-7: Spanish strains; lane 8: 100 bp DNA Ladder

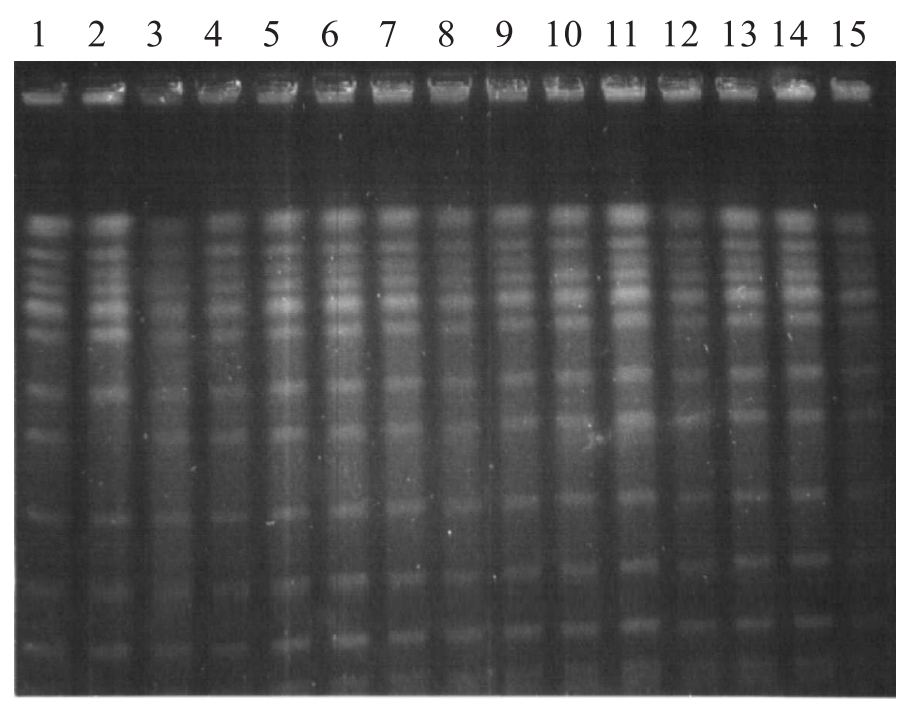

Fig. 3 - PFGE patterns of XbaI-digested chromosomal DNA from Argentinean strains. Lanes 1 to 3: strains HV141, HV2, and HG1. Lanes 4 to 15: strains SP30, SP31, SP32, SP33, SP34, SP94, SP97, SP98, SP99, SP100, SP102, and SP103.

\section{DISCUSSION}

Numerous papers about the clonal relationship between endemic Salmonella strains or between isolates involved in outbreaks can be encountered in scientific publications ${ }^{5,6}$ but to our knowledge, this represents the first study in Argentina in which a wide variety of epidemiological tools are applied to study Salmonella Infantis human isolates.

Several investigators have used the antimicrobial susceptibility typing of Salmonella strains for an epidemiological purpose $e^{3,9}$. However, we found that antimicrobial resistance was not very specific as an epidemiological marker due to the variability between the resistance profiles obtained.

Plasmid pattern analysis has been widely applied for the characterisation of epidemic strains and several authors ${ }^{13,16,24}$. Nevertheless, in our study the same plasmid profile was related with different antimicrobial resistance profile and vice versa and this could be due to the plasmids can be gained or loosed along a wide period of time ${ }^{10}$.

PCR-mediated genome fingerprinting based on ERIC or REP has been found useful for the typing of outbreak and sporadic Salmonella isolates. VERSALOVIC et al. ${ }^{28}$ used consensus PCR primers to amplify the REP and ERIC sequences in several bacterial species which were later applied by other investigators on several Salmonella serovars ${ }^{1,21}$. In our work, REP amplification data revealed the genetic homogeneity of epidemiologically related and geographically unrelated Argentinean strains, while Spanish strains showed four different banding patterns.

ERIC-PCR method was applied by several authors with good results among other serovars of Salmonella but not among Salmonella Infantis strains ${ }^{1,5}$. We found that this method, as it has been described previously, was not able to differentiate the strains studied, because the patterns obtained presented few clearly visible bands. May be this technique must 


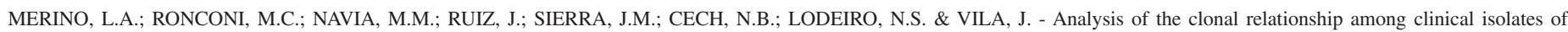
Salmonella enterica serovar Infantis by different typing methods. Rev. Inst. Med. trop. S. Paulo, 45(3):119-123, 2003.

be modified to find the most adequate conditions for Salmonella Infantis typing, but it is not the focus of this work.

The most powerful tool for discrimination of even closely related bacterial isolates has been reported to be the macrorestriction analysis of whole DNA by pulsed field gel electrophoresis (PFGE) ${ }^{21}$. Several restriction enzymes have been used for Salmonella strains typing, but not all are convenient for the analysis of Salmonella Infantis serovar ${ }^{11,18}$. $\mathrm{Xba \textrm {I }}$ is the most commonly used because it produces few and easily interpretable fragments.

In this work, all Argentinean strains, without regard to their origin, displayed identical PFGE patterns although different to those shown by the Spanish strains. MURAKAMI et al..$^{18}$ studied the genetic diversity among human and environmental Salmonella Infantis strains by PFGE, obtaining 35 distinct profiles and WEGENER \& BAGGESEN ${ }^{29}$ obtained 21 different PFGE profiles among Salmonella Infantis strains when studying 135 isolates from various sources. These findings support the fact of the clonal variability of Salmonella Infantis isolates.

At the start of this study, we expected that strains HG1, HV2 and HV141 would be epidemiologically different from the rest of the strains (SP30 to SP103), given their temporal and geographical diversity. However, their close genetic relatedness to the Salmonella Infantis strains isolated in Chaco and Corrientes is clearly demonstrated by the molecular methods applied. The cities of Juan José Castelli and Corrientes are distant 125 and 195 km, respectively, of Presidencia Roque Sáenz Peña. That is why it seems as though a single strain has been spread throughout a region of Argentina during a long lapse of time. A similar finding was reported by SULAKVELIDZE et al. ${ }^{26}$ when they studying two apparently distinct outbreaks in the Republic of Georgia.

In conclusion, antibiotype and plasmid profile was not useful as epidemiological tools. PFGE and REP-PCR were able to discriminate between Argentinean and Spanish isolates of Salmonella Infantis allowing to detect genetically related strains in three different cities. This finding indicates that a possible spread of a clone of this serovar in the Northeastern region of Argentina has taken place in 1998.

\section{RESUMEN}

\section{Análisis de la relación clonal entre aislamientos clínicos de Salmonella enterica serovar Infantis mediante diferentes métodos de tipificación}

Salmonella Infantis ha sido el segundo serovar más común en la Argentina en los últimos dos años, siendo aislada principalmente, a partir de pacientes pediátricos hospitalizados. La relación clonal entre 15 aislamientos de Salmonella Infantis obtenidos de heces de pacientes pediátricos en Argentina se estudió mediante la susceptibilidad antimicrobiana, el perfil plasmídico, amplificación por reacción en cadena de la polimerasa (PCR) de las secuencias repetitivas REP y ERIC, y electroforesis de ADN total en campo pulsátil (PFGE). Cuatro cepas españolas fueron incluidas como control de diversidad clonal. El antibiotipo y el perfil plasmídico no fueron herramientas útiles en la tipificación. PFGE y REP-PCR fueron capaces de discriminar entre las cepas argentinas y españolas de Salmonella Infantis, permitiendo detectar cepas genéticamente relacionadas en tres ciudades diferentes. Este hallazgo indica que una posible diseminación clonal de este serovar ha tenido lugar en la región nordeste de Argentina en 1998.

\section{ACKNOWLEDGMENTS}

This work was supported in part by grants from Fundación "Alberto J. Roemmers" and Secretaría General de Ciencia y Técnica (U.N.N.E.). We are grateful to Hospital Clinic i Provincial (Barcelona) for providing a research fellowship to L. A. Merino and to F. Uruburu Fernández for supplying us with strains from Spanish Collection of Type Cultures. We are also indebt to the staff of Instituto Nacional de Enfermedades Infecciosas ANLIS “Dr. Carlos G. Malbrán”, specially to R. Melano for technical advises and to M. I. Caffer for serotyping of strains.

\section{REFERENCES}

1.BEYER, W.; MUKENDI, F.M.; KIMMING, P. \& BÖHM, R. - Suitability of repetitiveDNA-sequence-based PCR fingerprinting for characterizing epidemic isolates of Salmonella enterica serovar Saintpaul. J. clin. Microbiol., 36: 1549-1554, 1998.

2. BOPP, C.A.; BRENNER, F.W.; WELLS, J.G. \& STROCKBINE, N.A. - Escherichia, Shigella and Salmonella. In: MURRAY, P.R.; BARON, E.J.; PFALLER, M.A.; TENOVER, F.C. \& YOLKEN, F.C., ed. Manual of clinical microbiology. 6. ed. Washington, ASM Press, 1995. p. 459-474

3. BORREGO, J.J.; CASTRO, D.; JIMENEZ-NOTARIO, M. et al. - Comparison of epidemiological markers of Salmonella strains isolated from different sources in Spain. J. clin. Microbiol., 30: 3058-3064, 1992.

4. GALLARDO, F.; RUIZ, J.; MARCO, F.; TOWNER, K.J. \& VILA, J. - Increase in incidence of resistance to ampicillin, chloramphenicol and trimethoprim in clinical isolates of Salmonella serotype Typhimurium with investigation of molecular epidemiology and mechanisms of resistance. J. med. Microbiol., 48: 367-374, 1999.

5. HELMUTH, R.; STEPHAN, R.; BUNGE, C. et al. - Epidemiology of virulence-associated plasmids and outer membrane protein patterns within seven common Salmonella serotypes. Infect. Immun., 48: 175-182, 1985.

6. HERMANS, P.W.M.; SAHA, S.K.; VAN LEEUWEN, W.J. et al. - Molecular typing of Salmonella typhi strains from Dhaka (Bangladesh) and development of DNA probes identifying plasmid-encoded multidrug-resistant isolates. J. clin. Microbiol., 34: 13731379,1996

7. KADO, C.I. \& LIU, S.T. - Rapid procedure for detection and isolation of large and small plasmids. J. Bact., 145: 1365-1373, 1981.

8. LLANES, C.; KIRCHGESNER, V. \& PLESIAT, P. - Propagation of TEM- and PSE-type $\beta$-lactamases among amoxicillin-resistant Salmonella spp. isolated in France. Antimicrob. Agents Chemother., 43: 2430-2436, 1999.

9. LUQUE, A.; MORIÑIGO, M.A.; RODRIGUEZ-AVIAL, C.; PICAZO, J.J. \& BORREGO, J.J. - Resistencias a antimicrobianos y presencia de plásmidos en cepas de Salmonella aisladas de diferentes orígenes. Enferm. infec. Microbiol. clin., 12: 187-192, 1994.

10. MARCO, F. \& JIMENEZ DE ANTA, M.T. - Métodos de tipificación: análisis de plásmidos. Ventajas e inconvenientes. Enferm. infec. Microbiol. clin., 11: 97-101, 1993.

11. MARISCAL LARRUBIA, A.; CLAVIJO FRUTOS, E.; CARNERO VARO, M. et al. Epidemiología molecular de toxiinfecciones producidas por Salmonella enterica: correlación del serotipo y del perfil proteico y análisis del ADN plasmídico. Enferm. infec. Microbiol. clin., 10: 328-333, 1992.

12. MATUSHEK, M.G.; BONTEN, M.J.M. \& HAYDEN, M.K. - Rapid preparation of bacterial DNA for pulsed-field gel electrophoresis. J. clin. Microbiol., 34: 25982600, 1996. 


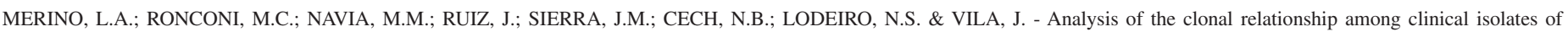
Salmonella enterica serovar Infantis by different typing methods. Rev. Inst. Med. trop. S. Paulo, 45(3):119-123, 2003.

13. MAYER, L.W. - Use of plasmid profiles in epidemiologic surveillance of disease outbreaks and in tracing the transmission of antibiotic resistance. Clin. Microbiol. Rev., 1 : 228-243, 1988.

14. MILLEMAN, Y. - Les marqueurs épidémiologiques des salmonelles. Vet. Res., 29: 3$19,1998$.

15. MILLER, S.I.; HOHMANN, E.L. \& PEGUES, D.A. - Salmonella (including Salmonella typhi). In: MANDELL, G.L.; BENNETT, J.E. \& DOLIN, R., ed. Principles and practice of infectious diseases. 4. ed. New York, Churchill, 1995. v. 2, p. 2013 2033

16. MILLS, L.; WOOLCOCK, J.B. \& COX, J.M. - Plasmid analysis of Australian strains of Salmonella Enteritidis. Lett. appl. Microbiol., 20: 85-88, 1995.

17. MUÑOZ, P.; DÍAZ, M.D.; RODRÍGUEZ-CRÉIXEMS, M. et al. - Antimicrobial resistance of Salmonella isolates in a Spanish hospital. Antimicrob. Agents Chemother., 37: 1200-1202, 1993.

18. MURAKAMI, K.; HORIKAWA, K. \& OTSUKI, K. - Genotypic characterization of human and environmental isolates of Salmonella choleraesuis subspecies choleraesuis serovar Infantis by pulsed-field gel electrophoresis. Microbiol. Immunol., 43: 293 296, 1999.

19. NAKAMURA, M.; SATO, S.; OHYA, T.; SUZUKI, S. \& IKEDA, S. - Plasmid profile analysis in epidemiological studies of animal Salmonella typhimurium infection in Japan. J. clin. Microbiol., 23: 360-365, 1986.

20. NATIONAL COMMITTEE FOR CLINICAL LABORATORY STANDARDS Performance standards for antimicrobial susceptibility testing. Ninth Informational Supplement. Wayne, Pennsylvania, NCCLS, 1999.

21. OLIVE, D.M. \& BEAN, P. - Principles and applications of methods for DNA-based typing of microbial organisms. J. clin. Microbiol., 37: 1661-1669, 1999.
22. PELKONEN, S.; ROMPPANEN, E.; SIITONEN, A. \& PELKONEN, J. - Differentiation of Salmonella serovar Infantis isolates from human and animal sources by fingerprinting IS200 and 16S rrn loci. J. clin. Microbiol., 32: 2128-2133, 1994.

23. PRELIMINARY foodnet data on the incidence of foodborne illness, selected sites, United States, 1999. M.M.W.R., 49(10): 201-205, 2000.

24. RIDLEY, A.M.; THRELFALL, E.J. \& ROWE, B. - Genotypic characterization of Salmonella enteritidis phage types by plasmid analysis, ribotyping, and pulsed-field gel electrophoresis. J. clin. Microbiol., 36: 2314-2321, 1998.

25. ROSSI, M.A.; GALAS, M.; CAFFER, M.I. et al. - Surveillance of Salmonella enterica antimicrobial resistance in Argentina. Different serovars, different resistance profiles. In: INTERNATIONAL CONGRESS ON INFECTIOUS DISEASES, 9., Buenos Aires, 2000. Abstract No. 43.008.

26. SULAKVELIDZE, A.; KEKELIDZE, M.; TURABELIDZE, D. et al. - Salmonellosis in the Republic of Georgia: using a molecular typing to identify the outbreak-causing strain. Emerg. infect. Dis., 6: 70-73, 2000.

27. TENOVER, F.C.; ARBEIT, R.D.; GOERING, R.V. et al. - Interpreting chromosomal DNA restriction patterns produced by pulsed-field gel electrophoresis: criteria for bacterial strain typing. J. clin. Microbiol., 33: 2233-2239, 1995.

28. VERSALOVIC, J.; KOEUTH, T. \& LUPSKI, J.R. - Distribution of repetitive DNA sequences in eubacteria and application to fingerprinting of bacterial genomes. Nucleic Acids Res., 19: 6823-6831, 1991.

29. WEGENER, H.C. \& BAGGESEN, D.L. - Investigation of an outbreak of human salmonellosis caused by Salmonella enterica ssp. enterica serovar Infantis by use of pulsed field gel electrophoresis. Int. J. Food Microbiol., 32: 125-131, 1996.

Received: 18 December 2002

Accepted: 22 May 2003 